\title{
Accumulation of Thallium in the Sediments of River Kortalaiyar in Tamilnadu, India
}

\author{
N. Bhuvana ${ }^{1}$, P. Prakash ${ }^{2}$ \\ ${ }^{1}$ Assistant Professor, Department of Chemistry, Jeppiaar Institute of Technology, Chennai, Tamilnadu, India \\ ${ }^{2}$ Assistant Professor, Department of Chemistry, Thiagarajar College, Madurai, Tamilnadu, India
}

\begin{abstract}
Kortalaiyar River is a source of freshwater for the residents of Tiruvallur district. It is one of the three rivers that flow in the Chennai metropolitan. The industries along the river mainly in Tiruvallur and Manali industrial belts open up their effluents into the river. In the present study samples of sediment was collected from 30 locations starting from Poondi Lake to Ennore creek to analyze the spatio-temporal variation of Thallium in the river sediments. The analysis was made more significant by determining the Geoaccumulation index, Enrichment factor and Contamination factor. Thallium is found to contaminate the river with its average composition of 2 ppm in comparison with a very low Upper Continental Crust composition of 0.75ppm.
\end{abstract}

Keywords: Kortalaiyar River, Geo-accumulation index, Enrichment factor, Contamination factor, Thallium

\section{Introduction}

The contamination of freshwaters due to several harmful substances, like metals, by the inputs from anthropogenic sources, industrial and agricultural activities, domestic sewage, groundwater leaching and runoffs from agriculture has devastating effects on the livestock found nearby. Rivers running through urban areas have also been faced water quality issues due to discharge of untreated domestic sewage, municipal wastes and industrial effluents into them leading to increase the metallic toxicity in the river waters. They get into the human food chain from environment. Once they enter our body system, they disturb the bio chemical process, sometimes leading to fatal results. Animals and plants require some trace elements for normal growth and development. But toxic elements like $\mathrm{As}, \mathrm{Pb}, \mathrm{Cd}, \mathrm{Hg}$ etc is required in trace quantities. According to the "International register of potentially toxic chemicals" of United Nations Environment Program, there are four million chemicals known in the world today and another 30,000 new compounds are added to the list every year. Among these 60,000 to 70,000 chemicals are commonly used.[1,2]Apart from their benefits to increasing production, living standards and health; many of them are potentially toxic.

\section{Study Area}

Kortalaiyar River is one of the three rivers that flow in the Chennai metropolitan area. The river has a length of $136 \mathrm{Km}$ and it originates near Kaveripakkam in Vellore district and finally drains into the Bay of Bengal. The main Kortalaiyar River flows into Poondi reservoir. The water flows through Thiruvallur district from the Poondi reservoir, enters into the Chennai metropolitan area, and joins the sea at Ennore creek. Whenever the flood gates of Poondi reservoir are opened, a considerable volume of water drains into the sea. through Kortalaiyar River near the Ennore Creek. The area for present study is 30 sampling points starting from Poondi reservoir to Ennore creek.

\section{Material and Methods}

Thirty samples of surface sediments were collected in an air dried Zip Lock covers for each season, Pre-Monsoon (PRM) and Post-Monsoon (POM) of two consecutive years from August 2012 to August 2014. The geographical locations of the sampling stations were marked using a Garmin eTrex hand-held GPS. The samples were collected from the surface of the river. The collected samples were tightly sealed in a zip lock cover and labeled before adopting laboratory geochemical analysis. The samples were dried in air and then powdered using an agate mortar. The powdered samples were sieved for further analysis to determine Thallium concentration [3].Geo-accumulation factor, Enrichment factor and Contamination Factor are determined using the standard methods [4-6].

\section{Results and Discussion}

Thallium (atomic number 81; CAS 7440-28-0) is a widely distributed, naturally occurring element in the earth's crust. Pure thallium is a tasteless and odourless, grayish white, soft and malleable heavy metal with a metallic lustre when freshly cut that quickly dulls to a bluish grey.

Thallium exists in two main oxidation states: Tl(I) (thallous) and $\mathrm{Tl}(\mathrm{III})$ (thallic), the former being more common and more stable. A rare and very unstable bivalent form ( $\mathrm{Tl}(\mathrm{II})$ ) is also known. Thallium is recovered commercially as a byproduct from sulphuric acid plants, cadmium refineries, and copper, zinc, and lead smelters. Thallium and its compounds are highly toxic and, thus, have limited industrial, agricultural, and medical uses. In the past, thallium sulphate was extensively employed as a rodenticide and an insecticide, but accidental poisonings and the misuse of these preparations for suicidal and homicidal purposes have led to the ban or restriction of all thallium-based pesticides in most countries. Tl-based insecticidal baits for ant traps were the only registered agricultural use for thallium until discontinued in 1974 [7].Thallium salts were once extensively prescribed to treat syphilis, gonorrhea, and 


\section{International Journal of Science and Research (IJSR) \\ ISSN (Online): 2319-7064 \\ Index Copernicus Value (2013): 6.14 | Impact Factor (2015): 6.391}

tuberculosis and as a depilatory in the treatment of ringworm infections in children.

However, the practice was discontinued because of highly toxic and often lethal side effects [8].At present, alloys of thallium are used in anode plates, low-temperature switches and seals, bearings, and contact points [8-10]. Thallium salts are used in semiconductor switches and closures, low-range thermometers, optical systems, infrared detectors, and photoelectric cells, and as a chemical intermediate for other thallium compounds and thallium metal[10,11]. Various thallium compounds are also used in the manufacture of spectrophotometers, photoelectric cells, high refractory lenses, low-melting glass, artificial gems, ceramic lenses, photographic and xerographic formulations, and fireworks $[10,11]$. Organothallium compounds are important reagents in organic chemical synthesis. Radioactive thallium (201Tl) is currently used for diagnostic purposes such as for myocardial scintigraphy[11]. Thallium is finding new applications in experimental high-temperature superconductors.

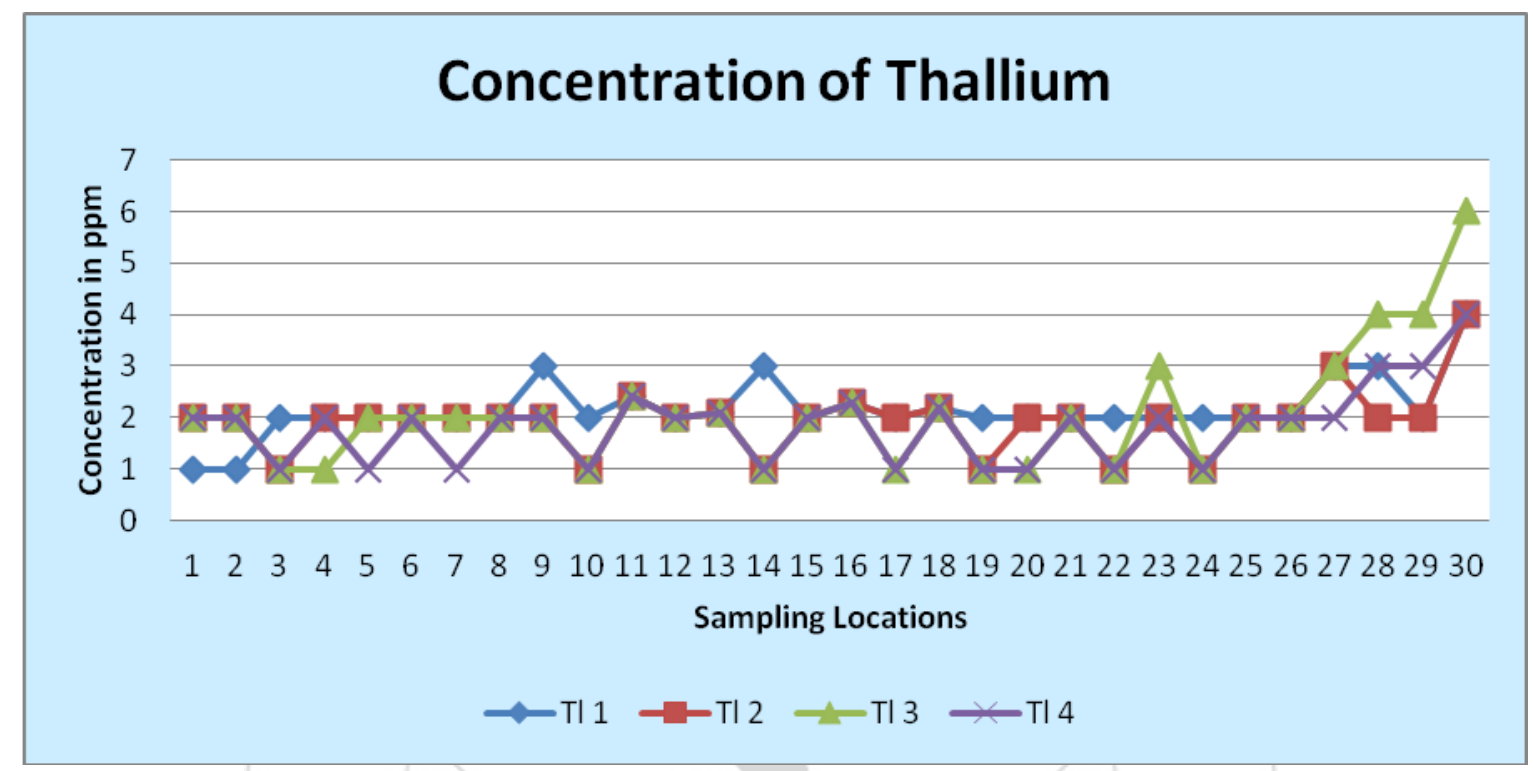

Figure 1: Spatio-temporal variation of Thallium

As a result of natural weathering, thallium is readily mobilized along with alkaline metals . However, as a result of human activities, an additional amount of $\mathrm{Tl}$ are mobilized globally each year. The major environmental releases of thallium are emissions and waste materials from the combustion of fossil fuels, ferrous and nonferrous smelting, metal processing, and cement production. No significant releases are expected from industries using thallium [11]. The behaviour of thallium in the atmosphere has been reviewed by USEPA in 1988 and [11]. Thallium compounds released to the atmosphere as a result of human activities are not volatile and are removed by precipitation, atmospheric dispersion, and gravitational settling [11]. Although some thallium compounds, such as $\mathrm{TlCl}$, are photosensitive, there is no evidence that photochemical reactions play a significant role in determining the atmospheric fate of thallium [11].

Thallium may partition from water to sediments [11] and sorb onto some clay minerals and hydrous metal oxides. Thus, it has been implied that sediments may act as an active sink for $\mathrm{Tl}$ in the aquatic environment [12].
The fate of thallium in soil and sediment was reviewed by $[13,14]$. In geochemical formations, thallium is known to occur in three oxidation states: Tl(I), Tl(II), and Tl(III). The cation $\mathrm{Tl}(\mathrm{I})$, mainly incorporated in sulphide, is highly associated with potassium and rubidium, Thallium is most often fixed in situ by clays and gels (colloids) of manganese and iron oxides, but the sorption of thallium by organic matter, especially under reducing conditions, is also known [13]. Thallous sulphate was found to be strongly bound in the upper $10 \mathrm{~cm}$ of various soil types and to strongly resist leaching to lower horizons [14]. Anthropogenic thallium in sediments appears to be very soluble and, thus, readily available to plants [13].

The concentration of Thallium along the Kortalaiyar river varies from $1 \mathrm{ppm}$ to $4 \mathrm{ppm}$ in PRM-1, $1 \mathrm{ppm}$ to $6 \mathrm{ppm}$ in PRM-2, $1 \mathrm{ppm}$ to $4 \mathrm{ppm}$ in POM-1 and $1 \mathrm{ppm}$ to $4 \mathrm{ppm}$ in POM-2. Figure1 shows the variation in the concentration of Thallium during the four seasons. The UCC value of $\mathrm{Tl}$ is recorded to be $0.75 \mathrm{ppm}$ [7]. The composition of $\mathrm{Tl}$ in Kortalaiyar river sediments shows the enrichment of $\mathrm{Tl}$ mainly due to weathering and sources of industrial effluent outputs. 


\section{International Journal of Science and Research (IJSR) \\ ISSN (Online): 2319-7064}

Index Copernicus Value (2013): 6.14 | Impact Factor (2015): 6.391

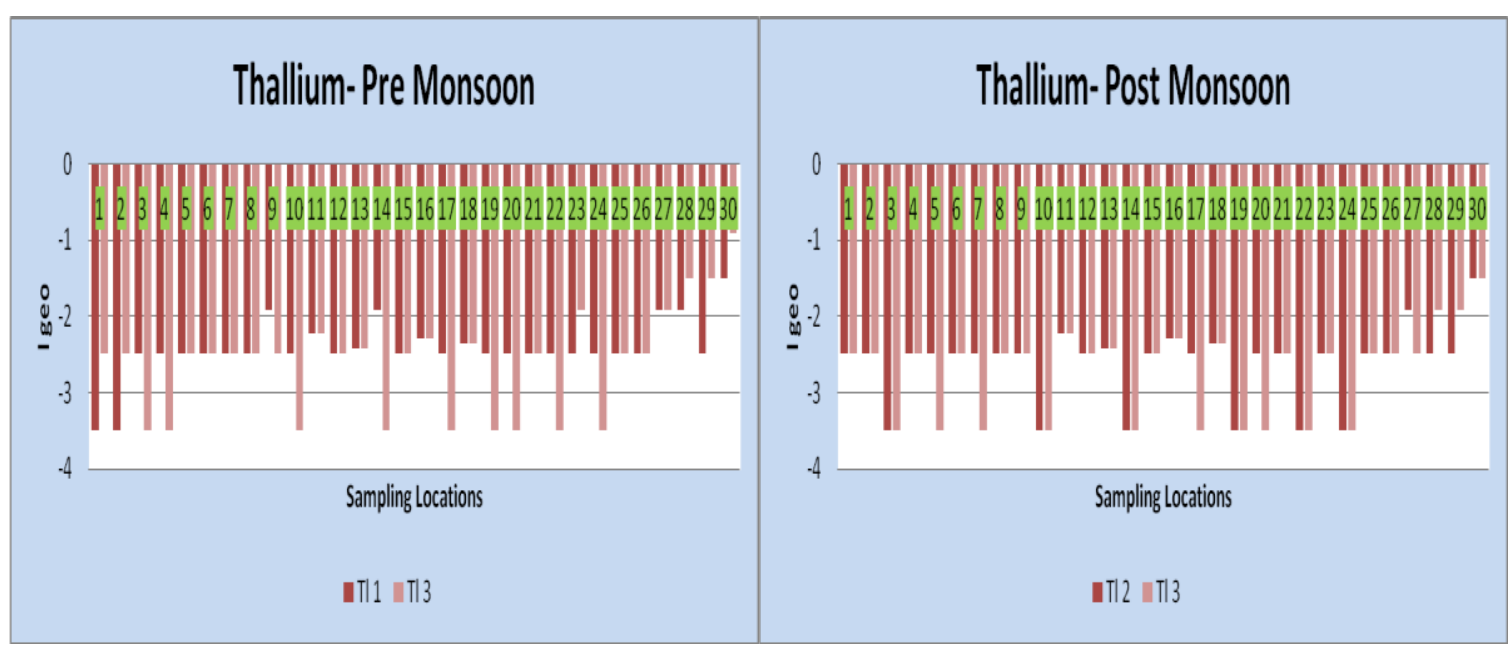

Figure 2: Geo-accumulation index of Thallium
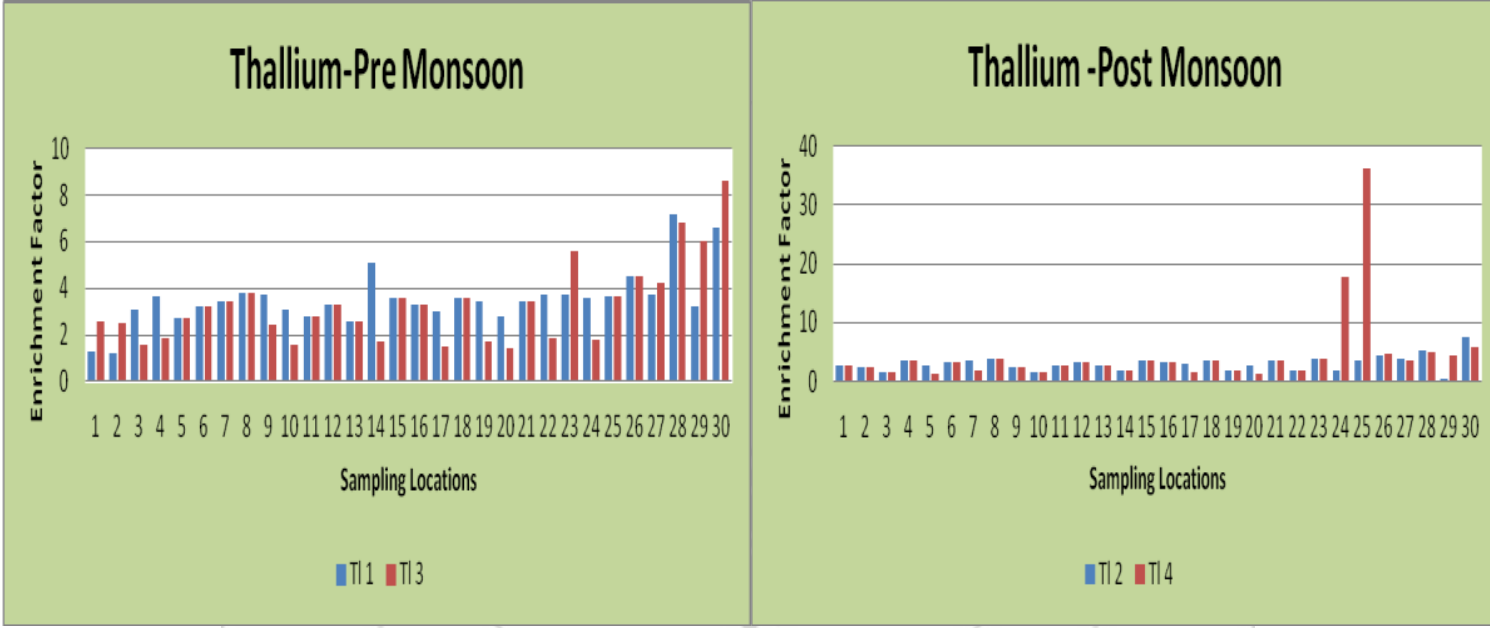

Figure 3: Enrichment Factor of Thallium

The variation of Igeo value of Tl in PRM and POM is shown in Figure 2. The contamination status of $\mathrm{Tl}$ comes under class 0 as all the sampling locations have Igeo less than 0 . Thus, the negatives Igeo values declare Kortalaiyar River sediments unpolluted by $\mathrm{Tl}$.

Thallium is enriched in minor level in the river flow area except in few sampling locations. Figure 3 shows the variation in EF of Tl with PRM and POM SL-28 and 30 is in moderately severe level of enrichment in PRM.SL-14 and 23 also shows the same level of enrihment in season-1 and 3 respectiely. In POM, the sampling locations except SL-24 and 25, are minorly enriched. SL-24 and 25 are severely enriched in the sediments during season- 4 .

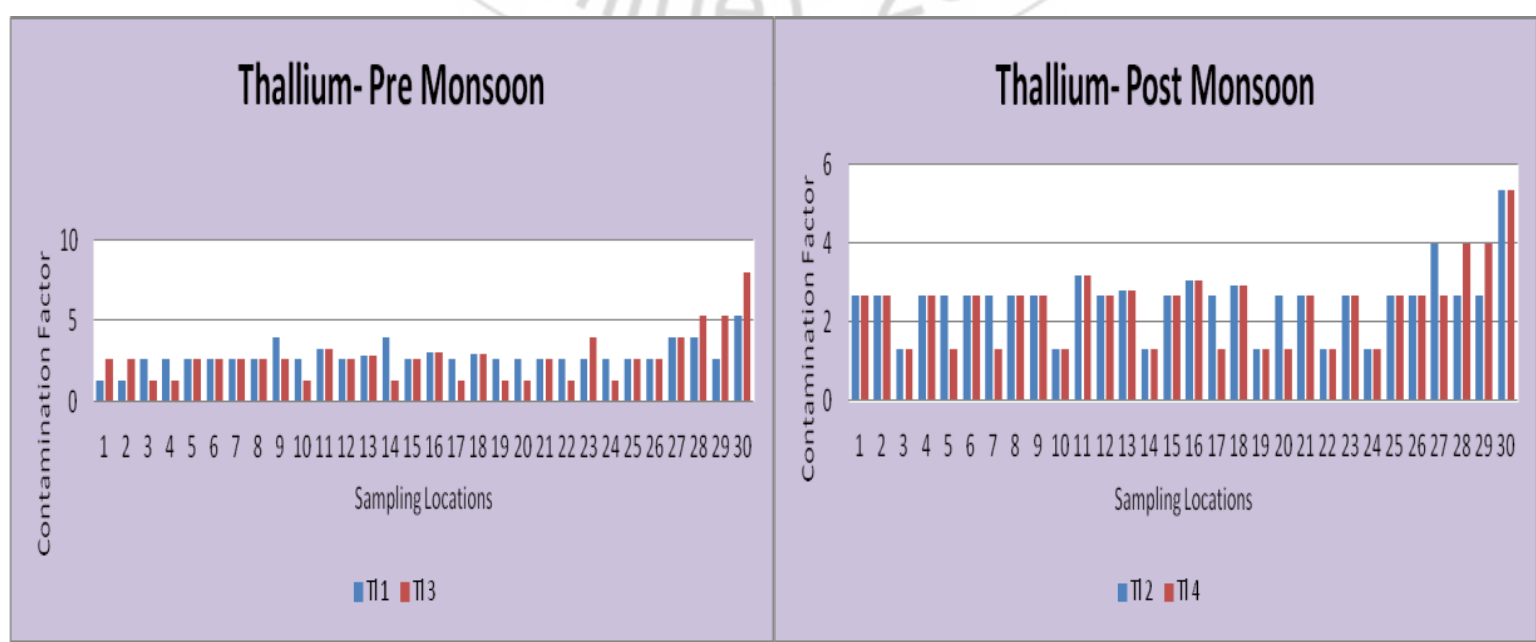

Figure 4: Contamination Factor of Thallium

Thallium reveals a $\mathrm{CF}$ range of 8 in SL-30 in season-2.This indicates very high degree of contmination in this location.
SL-9, 11, 14, 16, 23, 27, 28, 29 and 30 shows a considerable degree of contamination with $\mathrm{CF}$ varying from 3 to 5.3.The

\section{Volume 5 Issue 5, May 2016}




\section{International Journal of Science and Research (IJSR) \\ ISSN (Online): 2319-7064}

Index Copernicus Value (2013): 6.14 | Impact Factor (2015): 6.391

remaining locations indicate a moderate degree of contamination. Figure 4 shows the variation in $\mathrm{CF}$ of $\mathrm{Tl}$ during PRM and POM.

\section{Conclusion}

Large scale urbanization and agricultural activities have considerably complicated the natural pace of the sedimentation processes in the river. It is apparent that, irrational approaches to meet the quest of developmental activities have created severe impairments to the natural settings of the river. The natural and anthropogenic materials entering rivers are subjected to a series of mineralogical and chemical changes. Thallium is noted to be contaminated with the average composition of $2 \mathrm{ppm}$ in spite of a very low UCC composition of $0.75 \mathrm{ppm}$. Efforts are to be taken to monitor the accumulation of heavy metals like Thallium and make the river free from pollution. numerical methods in fluids 20, no. 8-9 (1995): 10811106.

[13] Ciszewski, D. "Flood-related changes in heavy metal concentrations within sediments of the Biala Przemsza River." Geomorphology 40, no. 3 (2001): 205-218.

[14] Moran, S. Bradley, and Robert M. Moore. "The distribution of colloidal aluminum and organic carbon in coastal and open-ocean waters off Nova Scotia." Geochimica et Cosmochimica Acta 53, no. 10 (1989): 2519-2527.

\section{References}

[1] Yadav, S. S., and Rajesh Kumar. "Assessment of ground water pollution due to fluoride content and water quality in and around Tanda Taluka of Rampur district, Uttar Pradesh, India." Journal of Chemical and Pharmaceutical Research 2, no. 4 (2010): 564-568..

[2] Hasan, I., Sultana Rajia, A. K. Kasi, and Gulshan Ara Latifa. "Comparative study on the water quality parameters in two rural and urban rivers emphasizing on the pollution level." Global Journal of Environmental Research 3, no. 3 (2009): 218-222.

[3] Loring, D. H., and R. T. T. Rantala. "Manual for the geochemical analyses of marine sediments and suspended particulate matter." Earth-science reviews 32 , no. 4 (1992): 235-283.

[4] Muller, G. "Index of geoaccumulation in sediments of the Rhine River." (1969): 108-118.

[5] Praveena, S. M., A. Ahmed, M. Radojevic, Mohd Harun Abdullah, and A. Z. Aris. "Factor-cluster analysis and enrichment study of mangrove sediments-an example from Mengkabong, Sabah." (2007).

[6] Chapman, P. M. "Determining when contamination is pollution-weight of evidence determinations for sediments and effluents." Environment International 33, no. 4 (2007): 492-501.

[7] Jones, B.F., and Carl J. Bowser. "The mineralogy and related chemistry of lake sediments." In Lakes, pp. 179235. Springer New York, 1978.

[8] Horowitz, A.J., and Kent A. Elrick. "The relation of stream sediment surface area, grain size and composition to trace element chemistry."Applied geochemistry 2, no. 4 (1987): 437-451.

[9] Forstner, U, G.T.W. Wittmann. Metal Pollution in the Aquatic Environment. 1979. Springer-Verlag, Berlin, Heidelberg, New York.

[10] Salomons, W. "Forstner U .1984. Metals in the hydrocycle."

[11] Jenne, E.A. "Trace element sorption by sediments and soils--sites and processes." In International Symposium on Molybdenum in the Environment. Denver, Colorado (USA). 1976.

[12]Liu, W. K, Sukky Jun, and Yi Fei Zhang. "Reproducing kernel particle methods." International journal for 